\section{Chickadees Back Again}

By Marion Nixon

My tame chickadee and her mate, who will almost but not quite trust me this winter ( though he fed reluctantly from my fingers and hat last winter ) are back, and a family with them. The day they arrived she scolded vociferously at the old feeding site till I came forth with peanuts, and on the second visit came to my hand. She will now climb all over my chin, or run up my face, seeking nuts between my lips. Quite out in the open, yesterday, she lit on my hand which held nothing, surveyed it, then my lips, then gave a disapproving dig at my thumb nail and flew off! She has quite a personality. I always know her voice from the cock's -- he runs variations into his calls, for one thing, and has a squeaker dee-dee for another -- but her form is much slimmer and smaller than any other of the chickadees which have fed from my trays. This is at least the third winter she has fed here. There is quite a thrill from having her come so trustfully to my hand.

We had a rare visitor about Christmas time. On December 28 a Canada Jay was seen sitting high in one of the spruce trees. It remained for only a brief while.

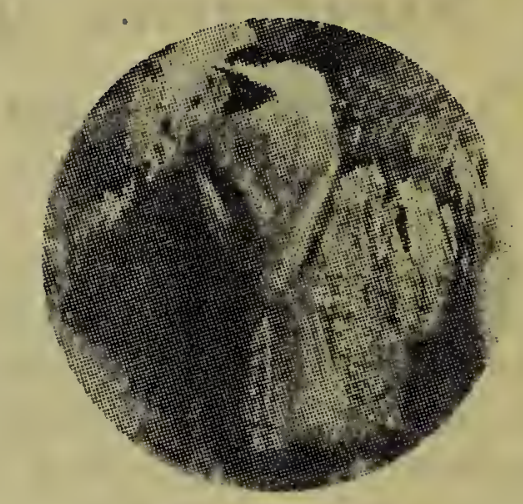

\section{Was the Flood Responsible?}

\author{
BY O. A. STEVENS
}

Prof. of Botany, N.D. Agriculture College, Fargo.

I notice that the Winnipeg people are attributing the flood and insecticides as a cause for scarcity of chickadees. We had years before when they were very scarce. I have just noted that none were included in my 1909 Christmas census. They seem very scarce here this year, but one woman along the river said she had seen lots of them. I have suspected that two might be "lots". We also have no Nuthatches and no Downy Woodpeckers at our feeding station. This is unusual.

Mrs. F. Bilsbury has reported that the usual numbers of chickadees in the Grenfell area are very conspicuous, this winter; by their absence.

\title{
Let the World Know
}

\section{BY J. H. YEREX, Clair}

This is the first time I have taken the opportunity of expressing my appreciation of this fine publication although I have been a subscriber since it first started. I, too, am anxious to see it grow and prosper, as a publication of this kind is needed very greatly, not only to us who are nature lovers, but to encourage others to become interested in this great hobby

My suggestion for increasing sub-scribers is to insert advertisements in all the farm papers, setting forth the merits of the BLUE JAY. I believe every school in Saskatchewan should have one or more copies sent to them every month. Maybe the Department of Education would co-operate with us in this respect. Pupils could be encouraged to report their finds or observations; a prize might even be offered from time to time for certain contributions. There are many, many people in this province who have never known thatsuch a wonderful publication exists. Many subscribers, no doubt, have just stumbled on to the BLUE JAY in the same way I did -- through "Chickadee Notes" in the Winnipeg Free Press.

Why not let the world know that there is a BLUE JAY published? 